
\title{
is Research Square \\ First Isolation and Molecular Characterization of Pseudorabies Virus Detected in Turkey
}

\section{Gizem Aytoğu}

Bursa Uludag University Faculty of Veterinary Medicine https://orcid.org/0000-0002-3411-081X

\section{Eda B. Toker}

Bursa Uludag University: Bursa Uludag Universitesi

Ozkan Yavas

Bursa Uludag University: Bursa Uludag Universitesi

\section{Berfin Kadiroglu}

Bursa Uludag University: Bursa Uludag Universitesi

\section{Ozer Ates}

Bursa Uludag University: Bursa Uludag Universitesi

\section{Musa Ozgur Ozyigit}

Bursa Uludag University: Bursa Uludag Universitesi

\section{Kadir Yesilbag ( $\nabla$ kyesilbag@uludag.edu.tr)}

Bursa Uludag University: Bursa Uludag Universitesi

\section{Research Article}

Keywords: Dog, Molecular characterization, Pseudorabies, Virus isolation

Posted Date: July 7th, 2021

DOI: https://doi.org/10.21203/rs.3.rs-659500/v1

License: (c) (i) This work is licensed under a Creative Commons Attribution 4.0 International License. Read Full License

Version of Record: A version of this preprint was published at Molecular Biology Reports on January 15th, 2022. See the published version at https://doi.org/10.1007/s11033-021-06974-x. 


\section{Abstract}

Pigs are the main host species for the pseudorabies virus, while it causes fatal encephalitis in many species including human being. The objective of this article is to report the first clinical case of pseudorabies as well as isolation and molecular characterization of the virus from a hunting dog in Bursa province, Turkey. The dog showing clinical signs including pruritus and neurological signs as stumbling and inability to stand up compatible with pseudorabies. The virus isolate was obtained from supernatant of fresh tissue samples from cerebellum, cornu ammonis, spleen, salivary gland, and conjunctival swab, as well as serum, and buffy coat samples. The glycoprotein $C$ region is targeted for viral DNA amplification. Pseudorabies virus genome was detected both in fresh tissues and supernatants of $3^{\text {rd }}$ passage on Vero cells. Number of PCR positive samples were dramatically increased after having cell culture inoculations. Genome sequencing revealed that the strain (Bursa-10303) isolated in Turkey where a non-endemic area is for the virus is dropped into clade A. This study confirms the presence of psedorabies infection in the wild life reservoirs in Turkey. Future studies may clarify the importance of the infection for Turkey where there is no common pig production.

\section{Introduction:}

Pseudorabies (PR), also called Aujesky's disease, is caused by Suide Herpesvirus-1 (SuHV-1, or synonymously Pseudorabies virus) which is a member of Alphaherpesvirinae subfamily within the family Herpesviridae [1]. Infection is an economic concern of swine industry. The agent is generally responsible for fatal infections and manifests as respiratory distress, nervous or genital disorders in pigs. However, high mortality rates are seen in piglets rather than swine. Like other Alphaherpesviruses, Pseudorabies virus (PrV) can develop lifelong latent infection in neuronal tissues of pigs. Even if the affected animal survives, the virus continues to circulate among the wild boar and domestic pig populations. Saliva, nasal discharge and airborne particles are the sources of transmission [2].

Swine (suids) known as primarily host and reservoir of PrV, but the virus also has a wide spectrum of host species including cattle, sheep, goat, dog, cat, chicken, rodents, rabbits and guinea pigs [1,3]. PRV is not only an important disease for animals but also for human. Moreover the infection can be sporadically transmitted to human being and may induce encephalitis $[4,5]$. However, inter-species transmission or evolution of PRV has been reported to vary between regions [2].Dogs are assessed to be secondary dead-end host and mostly infected by consuming contaminated pork meat or offal as well as direct contact with infected pigs [6].

PrV infection in dogs has been reported in different parts of the world. The regions where the presence of the infection in dogs has been reported include America, Europe, Austria and China until today [7-13]. This study describes the first isolation and genetic characterization of pseudorabies virus from hunting dog exhibited neurological signs in Turkey.

\section{Material Methods:}

\section{The case and samples}

Based on the alert by the field veterinarian, the case was a male dog exhibited same clinical findings typical for PrV. The dog owner also declared that the dog consumed raw pork offal. The dog came from Mustafakemalpaşa district of Bursa province, Turkey was presented to the veterinarian exhibiting difficulty in breathing, fever, unilateral ocular swelling and pruritis few days after consuming the raw meat. Few hours after reaching to the clinic, dog started to 
display stumbling and inability to stand up. The whole blood and serum samples were taken while the animal was alive, however, the dog died shortly after taking blood samples. Samples of cerebrum, cerebellum, cornu ammonis, lung, heart, lymph nodes, liver, spleen, duodenum, pancreas, kidney, salivary gland, conjunctival swab and also leukocyte and serum samples were collected at the necropsy.

After the PrV case was detected, a sampling was performed for antibody screening in hunting dogs in the region. For this purpose, blood serum was collected from 31 dogs actively used in pig hunting from Mustafakemalpaşa district where the infected dog is sheltered. Sera were obtained according to rules by national and local ethical committee (HADYEK; 2021-05/01). Blood samples were centrifuged at $1500 \mathrm{rpm}$ for $10 \mathrm{~min}$ for serum separation and $3000 \mathrm{rpm}$ for $10 \mathrm{~min}$ for peripheral blood mononuclear cell (PBMC) separation. Sera were heat inactivated at $56^{\circ} \mathrm{C}$ for $30 \mathrm{~min}$ and collected leukocytes re-suspended in phosphate-buffer saline (PBS), then stored at $-20^{\circ} \mathrm{C}$. Half part of the tissue samples were immersed in \%10 neutral buffered formaldehyde and the remained part was immediately used for virological examinations without freezing. The tissue samples were homogenized in PBS and were filtrated through $0.22 \mu \mathrm{m}$-pore filters after centrifugation at $3000 \mathrm{xpm}$ for $10 \mathrm{~min}$.

\section{Virus isolation}

The virus isolation was performed on Vero (African green monkey) and MDBK (Madin-Darby Bovine Kidney) cell lines. Supernatants of tissue homogenates $(0.1 \mathrm{ml})$ were inoculated and incubated for $60 \mathrm{~min}$ at $37^{\circ} \mathrm{C}$ in an atmosphere of $5 \% \mathrm{CO}_{2}$. After incubation, DMEM without fetal calf serum were added into each well and further incubated at $37^{\circ} \mathrm{C}$ for daily examination of cytopathogenic effect (CPE) using inverted light microscope. The virus isolation process was continued for 3 passages for all the samples in order to increase viral load for subsequent characterization. Viral titers in the samples with CPE in the third passage level in Vero cell line were calculated using the Spearman-Karber method.

\section{Histopathological analysis}

Specimens of brain, cerebellum, lungs, kidney, liver, spleen, heart and intestine were collected, fixed in 10\% buffered formalin solution and processed routinely. The samples were embedded paraffin, sectioned at $4 \mu \mathrm{m}$ and stained with hematoxylin and eosin.

\section{Virus neutralization assay}

The virus neutralization test (VNT) was performed for analyzing the antibody titer in diseased dog and also in serum samples from dogs possible have efficient contact to infected wild pigs in the region. Serial two-fold dilution, starting by $1: 2$, prepared in serum-free medium was mixed with equal volume of virus suspension with a titer of 100 $\mathrm{TCID}_{50}$ in 96-well tissue culture plate. After incubation for $120 \mathrm{~min}$ at $37^{\circ} \mathrm{C}$ and $5 \% \mathrm{CO}_{2}$ Vero cell suspension $\left(2 \times 10^{5}\right.$ cell/ml) was added. The plate was observed under an inverted light microscope for cpe during 4 days post infection.

\section{Virus identification}

Supernatants obtained from all the tissue samples and inoculated cell cultures where cpe observed were used for virus identification by Polymerase Chain Reaction (PCR). The DNA extraction was carried out by a commercial kit (Machery \& Nagel, Germany). Amplification of an 791bp fragment using primers gC-2U GTTTCCTGATTCACGCCCACGC and gC-1L GAAGGGCTCACCGAAGAGGAC [14] targeting a part of the gC (UL44) were performed using Dream Taq ${ }^{\mathrm{TM}}$ Hot Start PCR Master Mix (Thermo-Fisher Sci). PCR was performed with modifications as following conditions: denaturation step for 5 min at $95^{\circ} \mathrm{C}, 35$ cycles of $50 \mathrm{sec}$ at $55^{\circ} \mathrm{C}, 50 \mathrm{sec}$ at 
$60.7^{\circ} \mathrm{C}, 50 \mathrm{sec}$ at $72^{\circ} \mathrm{C}$ and final elongation step for $5 \mathrm{~min}$ at $72^{\circ} \mathrm{C}$. Sequence analysis was performed on the sample (cerebellum) which both showed the fast characteristic cpe appearance and strongest band on the gel. Obtained and References sequences (Table 1.) were edited using BioEdit soft ware and aligned with the ClustalW method. Phylogenetic analyzes inferred using Maximum-likelihood method with the Kimura two-parameter model, with 1000 replicates for bootstrap analyses, using MEGA X.

\section{Results:}

\section{Virus isolation:}

The dense rounded cells, diffuse degradation and lysis was detected in cell cultures inoculated with serum, cerebellum, cornu ammonis, spleen, salivary gland, conjunctival swab and PBMC samples (Fig. 1.). Virus isolation was repeated three times to increase the virus titer. But virus isolation could not be successfully performed in pancreas tissue because the adverse effect of its structure-specific enzymes. When the isolation process in cell lines was compared, there was no difference in the characteristic cpe appearance. In the first passage cpe was obtained in the both cell lines from different samples. Although cpe-like morphological changes were detected in the first passage, cpe could not be obtained from most of the samples in repetitive passages in the MDBK cell. Of all the samples, isolates in Vero cell line were obtained from serum, cerebellum, cornu ammonis, spleen, salivary gland, conjunctival swab and PBMC samples (Table 2.). But isolation was successful in both cell lines in cerebellum and spleen samples at all passage repeats.

\section{Molecular and sequence analysis:}

At the PCR performed on original samples a positive result is obtained in only one sample (cerebellum tissue). However, in all nucleic acid extracts from the 3rd passages of the samples creating cpe in the Vero cells $(n=7)$, the specific genomic sequence were amplified (Table 2.). To identify the molecular characteristics of the PrV isolate, gC gene of nucleotide sequence of cerebellum sample which was both positive from tissue sample and culture supernatant was analyzed. The amplified gC gene was $791 \mathrm{bp}$ in length. According to phylogenetic analyses, dog, domestic pig or wild boar sequences were not grouped in different branches separately but they were intertwined. The dog sequences were located both in clade A and B. It was observed that most of the sequences are not separated according to their geographical distribution as well. While most Asian sequences and also cattle isolate were found to be grouped outside clade $A$ and $B$ in the tree, it was determined that only one dog sequence obtained from China took place in clade A. Mentioned China sequence in clade A grouped with a vaccine strain and a dog strain from France (Fig. 2.). The genome sequence of isolate PRV/Dog/TR-Bursa-10303 grouped with wild boar, hunting dog and swine sequences from Belgium and Austria. On the alignment of sequences, similar to Yamagata S-81 strain, an amino-acid deletion in the strain TR-Bursa-10303 was detected in the nucleotide positions 71-73 when compared with the Kolchis (KT983811), (KJ717942), Yamagata (D49435) reference and Bartha (KY398740) vaccine strains (Fig. 4.). Some nucleotide deletions were also detected in amplified region. However, point mutations were found to be more common between positions 535-555. The sequence identity in the gC was $100 \%$ overlapped only with the strain BEL-55 (KF779462) Belgian isolate but varied between 98.16-99.75\% with aligned reference sequences in Fig. 3.

\section{Virus neutralization:}

Apart from these assays, no specific antibody against PrV virus was detected in the neutralization test performed with blood serum taken while the dog was alive. In addition, the presence of neutralizing antibodies was not 
detected in any of the blood samples randomly collected from the hunting dogs in the area where the infection was detected.

\section{Gross Lesions and Histopathology:}

At necropsy, diffuse bleeding areas in the brain, cerebellum, lung and intestine were observed. In histopathological examinations, diffuse haemorrhages were noticed in lung, kidney, spleen, liver and intestines particularly in duodenum. There was interalveolar thickening by mononuclear cells infiltration and edema formation. In liver, parenchymatous degeneration were observed. Severe degeneration of tubular epithelium in the kidney (Fig. 4) (for details see supplemental material).

\section{Discussion:}

Due to its excessive economic impact, some countries, including European Union (EU) member states, inserted PrV in surveillance programs and obtained PrV-free status in domestic pigs $[15,16]$. However, PrV present in wild boar and latent course of the virus continues to pose a risk to domestic animals. By examining the genetic similarities of the isolated strains, it has been shown that hunting dogs are also involved in this spill-over. In a research [15] relationship between hunting dogs and wild boars, and also sequence distinction of domestic pigs was shown. Besides clustering of canine PrVs together with isolates of pigs and wild boars suggests that canine PrV isolates may have originated from pigs [2].

The first reported case of PrV in Turkey was in a cow from eastern part of the country detected by immunohistochemical staining in 2016 [17]. Although rare human cases have been reported around the world, there are no reported human case in Turkey. In addition, there is no reported clinical case, including virological confirmation and characterization in Turkey. However, the detected PrV isolate from a hunting dog in this study in the northwestern part of the country after a cattle case in the eastern end [17], demonstrates that there may be an endemic status of the infection in wild boars in the country. Apart from this findings, veterinarians may not need laboratory diagnosis due to the rapidly developed death which occurs within 6-48 hours following the onset of clinical symptoms in dogs $[13,15]$ or they may not consider PrV as a causative factor. For these reasons, there may be deficiencies in detecting the possible circulation of PrV infection.

The PrV antibody prevalence can be used to evaluate the presence of infection in a region mostly for pigs [16] but dogs as well. ELISA method is predominantly preferred in serological screenings and virus neutralization assay is included in a small range. In China [18], the presence of antibodies in 6 of 19 dog sera housed in pig farms or pet hospitals by ELISA method was demonstrated. In addition, the presence of antibodies was demonstrated by VNT in 2 of 466 samples in hunting dogs in Spain [10]. By VNT the presence of antibodies in a recent outbreak in cattle in Italy has also been reported [19]. However, the dog sera tested in this study was found to be antibody negative. For PrV, the incubation period in dogs is usually 2-9 days long [20]. The period between the dog's ingestion of pork meat and its death in this study is not more than a week. Seronegative detection in the virus neutralization test of the examined dog, is thought to be due to the incubation time, which may be insufficient for the development of detectable antibody response. At the same time, no antibodies were detected in the sera obtained from dogs that are actively used for pig hunting in the region. In this case, a definite conclusion could not be created about the prevalence of the disease in the region. A survey of wild boars may help to better understanding of the epidemiology of PrV in Turkey. 
PrV can infect various types of cell cultures. In addition to Vero cell line which is frequently used, studies have also been carried out on the MDBK cell line [21, 22]. Wang et al. revealed that there were no significant difference between the one-step growth kinetics of three different PrV strains, but in plaque sizes. Though stated difference in cpe in comparison of variants of PrV[23]. In this study, unexpectedly, it was determined that cpe-like morphological changes couldn't be detected at following passage levels of most samples in the MDBK cells. While cpe was detected at isolations of 7 samples in Vero cell line, it was only detected at two tissue samples in MDBK cell line. Though when obtained isolate numbers were compared, obtaining only 2 isolates in the MDBK cell line shows that preferring the Vero cell line for isolation studies will provide more successful results.

Besides, all of the PCR tests performed on the samples directly, except cerebellum, were negative, while all the identification tests performed on the cell supernatants with cpe were positive. This may be attributed to the low amount of viral load in other tissues. Results of this study indicates that cell culture isolation, which is considered as the gold standard, still has a stronger reliability. In genotyping analyses various sequences from all over the world including European, American or Asian territories are included. Due to the main route of transmission to dogs is the consumption of infected meat, wild pig and dog sequences are mainly included in the tree. The homogeneous distribution in phylogenetic analysis and absence of grouping according to host category supports the circulation by interspecies transmission. According to the information obtained from the animal owners during the sera sampling of the dogs in the region, it was learned that animals in that region could be given adopted voluntarily to Greece. Finding similarities of the current sequence can be attributed to facilitate the tracing in future. In alignment investigation PRV/Dog/TR-Bursa-10303 sequence was identical with a Belgium isolate (BEL-55) for the analysed $791 \mathrm{bp}$ region of gC. And also both grouped with Austria strains. High similarity levels of samples from such distant geographies rather than sequence data from neighboring countries is still obscure.

\section{Conclusion:}

While the notification of infection in domestic pigs decreases in some regions of the world, PrV reported in dogs from different parts of the world is increasing $[9,10,13,15,16,24]$. The genomic characterization of PrV from secondary host as obtained in this study will help to trace the population diversity and infection origin for the areas where the disease has not yet been detected or is still a problem. Future studies are warranted to assess the prevalence PrV infections in the country in order to take precautions for the future.

\section{Declarations:}

\section{Acknowledgements}

The authors thank veterinarian Dr. Evren Bulgaç for presenting the case and providing the samples.

\section{Conflict of interest}

The authors declare that they have no conflicts of interest.

\section{References:}

1. Pomeranz LE, Reynolds AE, Hengartner CJ (2005) Molecular Biology of Pseudorabies Virus: Impact on Neurovirology and Veterinary Medicine. Microbiol Mol Biol Rev 69:462-500 . doi: 10.1128/mmbr.69.3.462500.2005 
2. He W, Auclert LZ, Zhai X, et al (2019) Interspecies Transmission, Genetic Diversity, and Evolutionary Dynamics of Pseudorabies Virus. J Infect Dis 219:1705-1715 . doi: 10.1093/infdis/jiy731

3. Mettenleiter TC (2000) Aujeszky's disease (pseudorabies) virus: The virus and molecular pathogenesis - State of the art, June 1999. Vet Res 31:99-115 . doi: 10.1051/vetres:2000110

4. Wang D, Tao X, Fei M, et al (2020) Human encephalitis caused by pseudorabies virus infection: a case report. J Neurovirol 26:442-448 . doi: 10.1007/s13365-019-00822-2

5. Wong G, Lu J, Zhang W, Gao GF (2019) Pseudorabies virus: a neglected zoonotic pathogen in humans? Emerg. Microbes Infect. 8:150-154

6. Kaneko C, Kaneko Y, Sudaryatma PE, et al (2021) Pseudorabies virus infection in hunting dogs in Oita, Japan: report from a prefecture free from Aujeszky's disease in domestic pigs. J Vet Med Sci. doi: 10.1292/jvms.200450

7. Pedersen K, Turnage CT, Gaston WD, et al (2018) Pseudorabies detected in hunting dogs in Alabama and Arkansas after close contact with feral swine (Sus scrofa). BMC Vet Res 14:388 . doi: 10.1186/s12917-0181718-3

8. Tu L, Lian J, Pang Y, et al (2021) Retrospective detection and phylogenetic analysis of pseudorabies virus in dogs in China. Arch Virol 166:91-100 . doi: 10.1007/s00705-020-04848-4

9. Serena MS, Metz GE, Lozada MI, et al (2018) First isolation and molecular characterization of suid herpesvirus type 1 from a domestic dog in Argentina. Open Vet J 8:131-139 . doi: 10.4314/ovj.v8i2.3

10. Cano-Terriza D, Martínez R, Moreno A, et al (2019) Survey of Aujeszky's Disease Virus in Hunting Dogs from Spain. Ecohealth 16:351-355 . doi: 10.1007/s10393-019-01426-2

11. Fray MD, Paton D., Alenius S (2000) The effects of bovine viral diarrhoea virus on cattle reproduction in relation to disease control. Anim Reprod Sci 60:615-627 . doi: 10.1016/S0378-4320(00)00082-8

12. Steinrigl A, Revilla-Fernández S, Kolodziejek J, et al (2012) Detection and molecular characterization of Suid herpesvirus type 1 in Austrian wild boar and hunting dogs. Vet Microbiol 157:276-284 . doi: 10.1016/j.vetmic.2011.12.033

13. Cramer SD, Campbell GA, Njaa BL, et al (2011) Pseudorabies virus infection in Oklahoma hunting dogs. J Vet Diagnostic Investig 23:915-923 . doi: 10.1177/1040638711416628

14. Fonseca AA, Camargos MF, de Oliveira AM, et al (2010) Molecular epidemiology of Brazilian pseudorabies viral isolates. Vet Microbiol 141:238-245 . doi: 10.1016/j.vetmic.2009.09.018

15. Moreno A, Sozzi E, Grilli G, et al (2015) Detection and molecular analysis of Pseudorabies virus strains isolated from dogs and a wild boar in Italy. Vet Microbiol 177:359-365 . doi: 10.1016/j.vetmic.2015.04.001

16. Pedersen K, Turnage CT, Gaston WD, et al (2018) Pseudorabies detected in hunting dogs in Alabama and Arkansas after close contact with feral swine (Sus scrofa). BMC Vet Res 14:388 . doi: 10.1186/s12917-0181718-3

17. Yildirim S, Özkan C, Yener Z, et al (2017) Van'da bir ınekte yalancı kuduz (aujeszky) hastalığının ımmunohistokimyasal teşhisi. Kafkas Univ Vet Fak Derg 23:173-176 . doi: 10.9775/kvfd.2016.16071

18. Lin W, Shao Y, Tan C, et al (2019) Commercial vaccine against pseudorabies virus: A hidden health risk for dogs. Vet Microbiol 233:102-112 . doi: 10.1016/j.vetmic.2019.04.031

19. Ciarello FP, Capucchio MT, Ippolito D, et al (2020) First report of a severe outbreak of Aujeszky's disease in Cattle in Sicily (Italy). Pathogens 9:1-15 . doi: 10.3390/pathogens9110954 
20. Zhang L, Zhong C, Wang J, et al (2015) Pathogenesis of natural and experimental Pseudorabies virus infections in dogs Herpes viruses. Virol J 12: . doi: 10.1186/s12985-015-0274-8

21. Karger A, Schmidt J, Mettenleiter TC (1998) Infectivity of a Pseudorabies Virus Mutant Lacking Attachment Glycoproteins C and D

22. Wu YQ, Chen DJ, He H Bin, et al (2012) Pseudorabies virus infected porcine epithelial cell line generates a diverse set of host microRNAs and a special cluster of viral microRNAs. PLoS One 7: . doi: 10.1371/journal.pone.0030988

23. Wang X, Wu CX, Song XR, et al (2017) Comparison of pseudorabies virus China reference strain with emerging variants reveals independent virus evolution within specific geographic regions. Virology 506:92-98 . doi: 10.1016/j.virol.2017.03.013

24. Tu L, Lian J, Pang Y, et al (2021) Retrospective detection and phylogenetic analysis of pseudorabies virus in dogs in China. Arch Virol 166:91-100 . doi: 10.1007/s00705-020-04848-4

\section{Tables:}

Table 1. Origin, species and accession numbers of reference sequences strains used for phylogenetic analyses. 


\begin{tabular}{|c|c|c|c|c|c|c|c|c|c|}
\hline $\begin{array}{l}\text { Accession } \\
\text { number }\end{array}$ & Year & Origin & $\begin{array}{l}\text { Species } \\
\text { (attitude) }\end{array}$ & Clade & $\begin{array}{l}\text { Accession } \\
\text { number }\end{array}$ & Year & Origin & $\begin{array}{l}\text { Species } \\
\text { (attitude) }\end{array}$ & Clade \\
\hline JQ081290 & 2010 & Austria & Wild boar & A & KF779462 & 1976 & Belgium & Swine & A \\
\hline JQ081292 & 2010 & Austria & $\begin{array}{l}\text { Hunting } \\
\text { dog }\end{array}$ & $A$ & KF779465 & 1988 & Belgium & Swine & A \\
\hline JQ081284 & 2005 & Austria & $\begin{array}{l}\text { Hunting } \\
\text { dog }\end{array}$ & $A$ & KP862617 & 2012 & Italy & Dog & A \\
\hline KP862619 & 2014 & Italy & $\begin{array}{l}\text { Hunting } \\
\text { dog }\end{array}$ & $A$ & KP780805 & 1993 & Italy & Dog & A \\
\hline KP862614 & 2011 & Italy & $\begin{array}{l}\text { Hunting } \\
\text { dog }\end{array}$ & $A$ & KF779458 & 2007 & Belgium & $\begin{array}{l}\text { Hunting } \\
\text { dog }\end{array}$ & B \\
\hline MN590177 & 2017 & France & Dog & $A$ & MN590215 & 2009 & France & Dog & B \\
\hline MN590216 & 2017 & France & Dog & $A$ & GQ259100 & 1999 & France & $\begin{array}{l}\text { Hunting } \\
\text { dog }\end{array}$ & B \\
\hline MF101748 & 2015 & Argentina & $\begin{array}{l}\text { Domestic } \\
\text { dog }\end{array}$ & $A$ & GQ259125 & 2004 & Spain & $\begin{array}{l}\text { Wild } \\
\text { boar }\end{array}$ & B \\
\hline JQ768125 & 2007 & Italy & Dog & $A$ & GQ259107 & 2000 & Germany & $\begin{array}{l}\text { Wild } \\
\text { boar }\end{array}$ & B \\
\hline JF767011 & 2010 & Oklahoma & $\begin{array}{l}\text { Hunting } \\
\text { dog }\end{array}$ & A & GQ259099 & 1999 & France & $\begin{array}{l}\text { Hunting } \\
\text { dog }\end{array}$ & B \\
\hline KJ717942 & - & Hungary & Wild boar & $A$ & MN443965 & 2018 & China & Dog & Asian \\
\hline KT983811 & 2010 & Greece & Wild boar & A & AF158090 & - & China & Swine & Asian \\
\hline KY398740 & 2011 & - & $\begin{array}{l}\text { Bartha- } \\
61 / \text { cell } \\
\text { strain }\end{array}$ & A & KP098534 & 2012 & China & $\begin{array}{l}\text { Wild } \\
\text { boar }\end{array}$ & Asian \\
\hline MN443969 & 2018 & China & Dog & A & KM061380 & 2012 & China & $\begin{array}{l}\text { Wild } \\
\text { boar }\end{array}$ & Asian \\
\hline D49435 & 1996 & Japan & Swine & A & AF403051 & 1962 & China & Cattle & Asian \\
\hline
\end{tabular}

Table 2. Comparison of PrV positivity results obtained by PCR and virus isolation. 


\begin{tabular}{|c|c|c|c|c|}
\hline \multirow[t]{2}{*}{ Sample } & Virus isolation results $\rrbracket$ & Virus titers* & \multicolumn{2}{|l|}{ PCR results } \\
\hline & (in Vero cells) & & Tissue sample & Cell supernatant \\
\hline Serum sample & $3 p$ & $10^{5,0}$ & - & + \\
\hline PBMC & $3 p$ & $10^{3,5}$ & - & + \\
\hline Salivary gland & $3 p$ & $10^{5,25}$ & - & + \\
\hline Conjunctival swab & $1 p$ & $10^{5,75}$ & - & + \\
\hline Cerebrum & - & $N P$ & - & $N P$ \\
\hline Cerebellum & $1 p$ & $10^{5,0}$ & + & + \\
\hline Cornu ammonis & $3 p$ & $10^{5,75}$ & - & + \\
\hline Lung & - & $N P$ & - & $N P$ \\
\hline Heart & - & $N P$ & - & $N P$ \\
\hline Lymph nodes & - & $N P$ & - & $N P$ \\
\hline Liver & - & - & - & $N P$ \\
\hline Spleen & $1 p$ & $10^{5,0}$ & - & + \\
\hline Duodenum & - & - & - & $N P$ \\
\hline Pancreas & $N P$ & $N P$ & - & $N P$ \\
\hline Kidney & - & $N P$ & - & $N P$ \\
\hline
\end{tabular}

(*): presented as $\operatorname{TCID}_{50} 10^{\mathrm{x}} / 0,1 \mathrm{ml}$ at $3^{\text {rd }}$ passage, ():the passage number which the first cpe is detected, $(N P)$ : the corresponding analysis is "not performed" in this sample, (-): not detected.

\section{Figures}




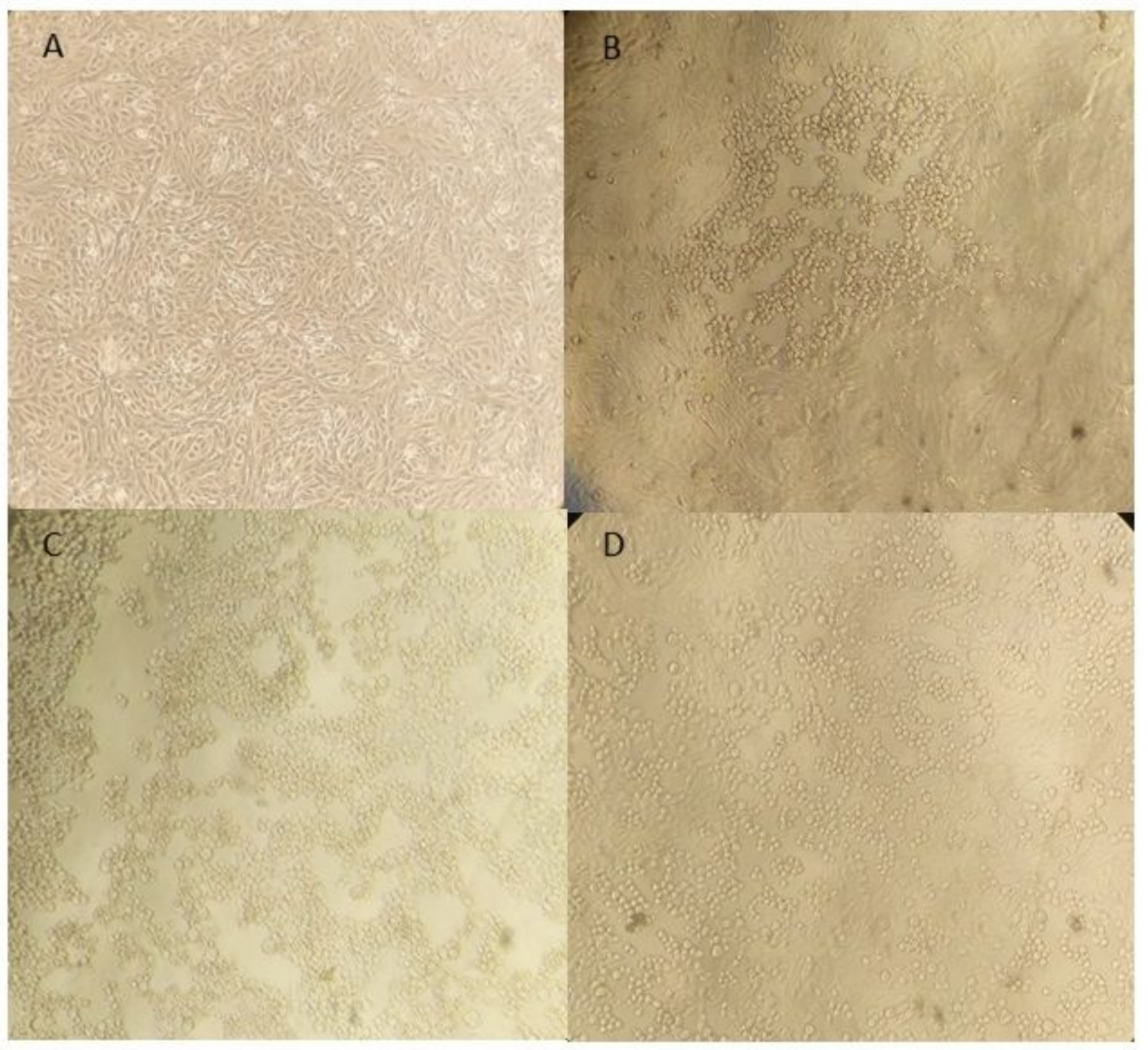

\section{Figure 1}

Cytopathic effect caused by the isolate TR-Bursa-10303 on Vero cell line $(\times 10)$. Vero monolayer $(A)$ non infected cell control well, (B) second day of the cell line infected with PBMC sample, (C) third day of the cell line infected with cornu ammonis supernatant (D) third day of the cell line infected with conjunctival swab sample. 


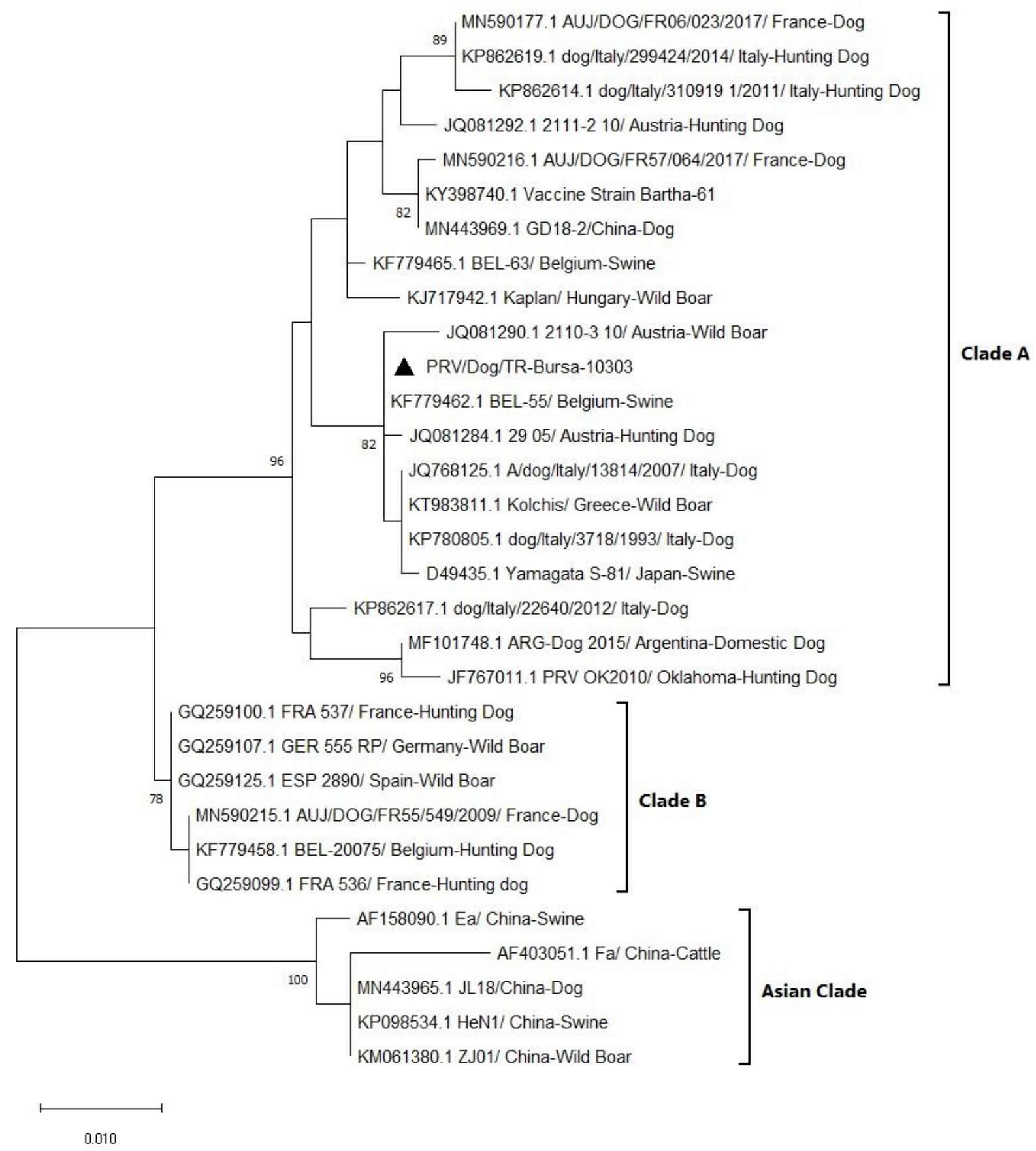

Figure 2

Phylogenetic tree presenting the position of isolate PRV/Dog/TR-Bursa-10303 in Clade A. The target sequences are on $\mathrm{gC}$ genomic region of the pseudorabies virus strains. The tree was obtained using maximum likelihood method with 1000 bootstrap replicates. The Turkish dog sequence was shown as marked. 


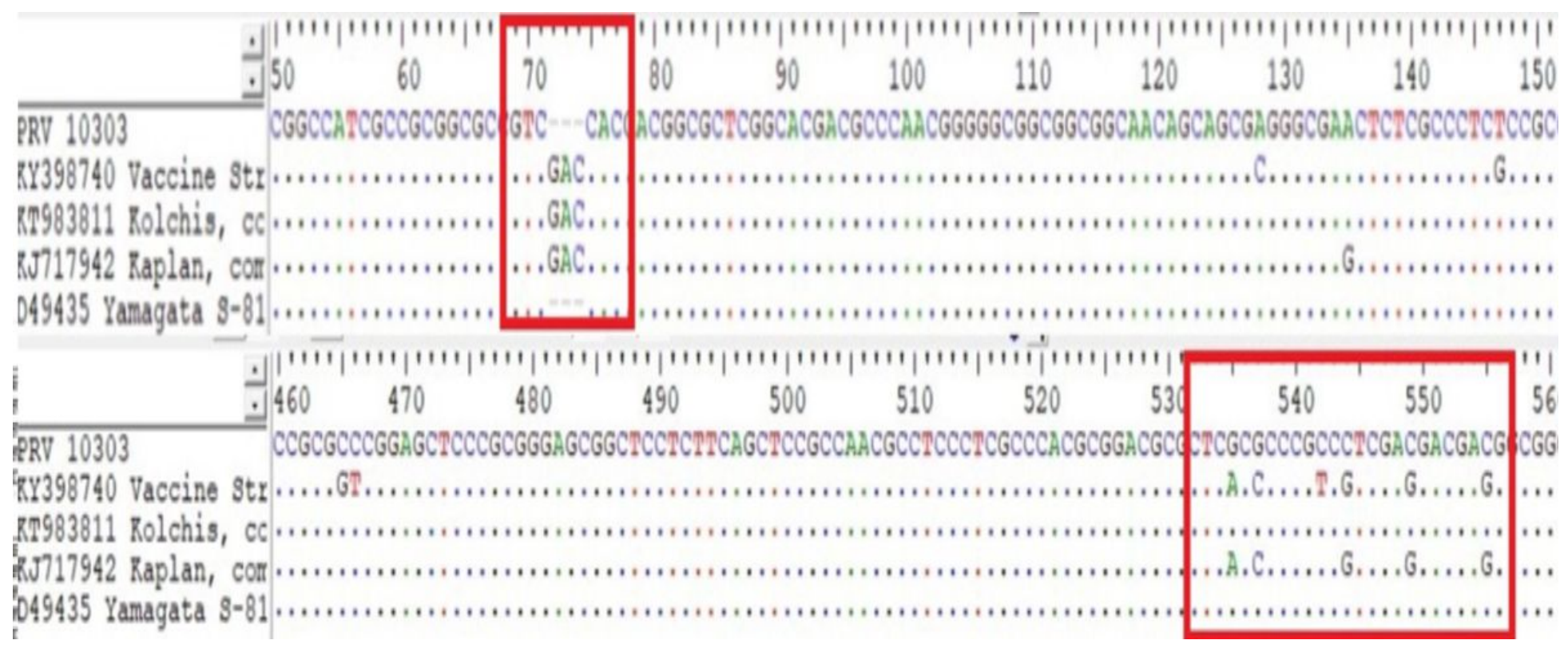

\section{Figure 3}

Alignment of deduced nucleotide sequences of gC coding region. Alterations are indicated in boxes.

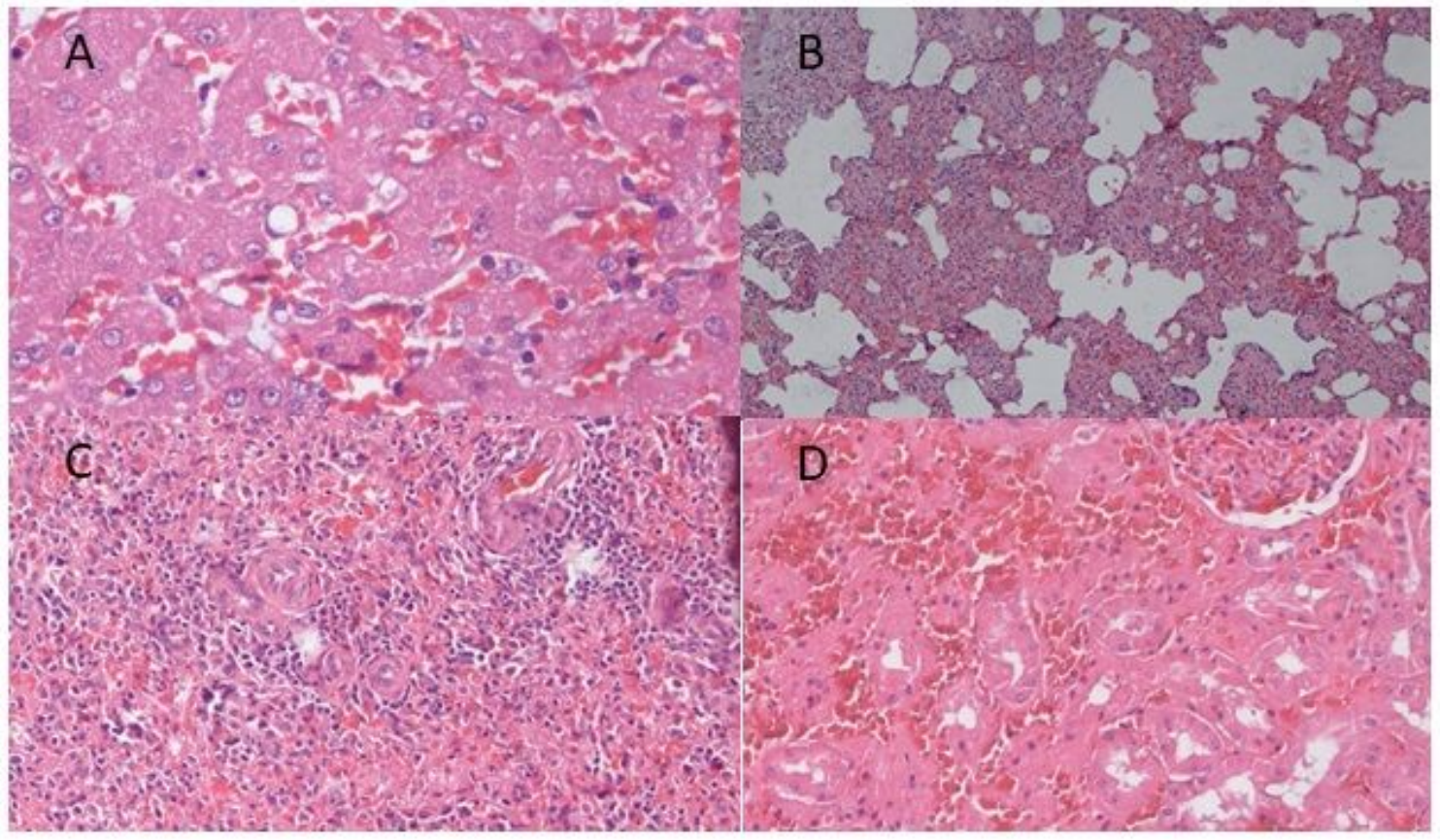

\section{Figure 4}

H\&E staining in histopathological study of PrV infected dog tissues. (A) Extensive liver degeneration, 40x, $H-E,(B)$ Thickening and hyperemia in the interstitial area of the lung,10x, H-E, (C) Hassal corpuscular in the spleen, 20x, H-E, (D) Severe bleeding and tubular degeneration in the interstitial area and glomerulus of the kidney 20x, H-E

\section{Supplementary Files}

This is a list of supplementary files associated with this preprint. Click to download. 
- SuplementarymaterialArchVirol.docx

Page 14/14 